\title{
The budget control in the function of the civil and democratic control of the armed forces in the Republic of Serbia
}

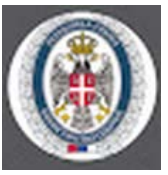

Received: 23/09/2021 Revised: 04/10/2021

Accepted: 08/10/2021

Published: 06/12/2021

Corresponding author: Milena Knežević

Correspondence email: milena.knezevic@mod.gov.rs

DOI: $10.5937 /$ vojdelo2103103K \begin{tabular}{|l|l|l|l|}
\hline c & e & o & n \\
\hline c & e & e & s \\
\hline
\end{tabular}

\author{
Milena Knežević, Srboljub Nikolić1, Aleksandar Neševski \\ 'Univerzitet odbrane u Beogradu, Vojna akademija \\ ${ }^{2}$ Univerzitet odbrane u Beogradu, Rektorat
}

\begin{abstract}
:
One of the important indicators of democratization of each society is the constitutional and legal definition of the role of the military and the possibility of its control. The civil and democratic control of the Serbian Armed Forces primarily includes control of the use and development of the Serbian Armed Forces, internal and external control of the expenditures for the military needs, monitoring and informing the public about the state of preparations of the Armed Forces, providing free access to information of public importance and defining responsibilities for performing the military duties in accordance with the law. The instrument for financing the military expenditures in the Republic of Serbia is the state budget. During the drafting of the Law on Budget, the costs for the military needs are planned for the budget year and the following two years. Having in mind that the Law on Budget is passed by the highest legislative body - the National Assembly, the main principle of the democratic control of the military expenditure planning is provided. However, the budget execution implies the control over the use of the budget funds, whereby the Law on Budget System provides for several levels of control, organized as internal and external control. The internal control of the military expenditures, expressed in the budget of the Republic of Serbia, is carried out by the financial service bodies of the units and institutions of the Serbian Armed Forces, the Accounting Centre of the Budget and Finance Sector of the Ministry of Defence, the Defence Inspectorate, the Military Security Agency, the Criminal Investigation Group and the Internal Audit of the Ministry of Defence. The external control of the budget intended for the military needs is performed by the State Audit Institution and the Budget Inspection. The objective of the control is to determine whether the actions of the Serbian Armed Forces are in accordance with the position stipulated by the Constitution, as well as with the policy that the mentioned representative and executive authorities define in their acts.
\end{abstract}

Keywords: civil and democratic control; budget; efficiency; execution

\section{INTRODUCTION}

The purpose of this research is better understanding of one of the mechanisms of the civil and democratic control of the Serbian Armed Forces through "the control of the military budget". The civil and democratic control of the Serbian Armed Forces is stipulated by Article 141 of the Constitution of the Republic of Serbia, while Article 99 of the Constitution defines that the National Assembly supervises the work of security services including the Ministry of Defence and the Serbian Armed Forces.

The civil and democratic control of the Armed Forces is not the creation of the modern society and that is why it is interesting to cite the opinion of the Serbian military leader Živojin Mišić (1885-1921): "The life of a cultural nation in the modern state can be studied from the political, economic and financial, educational and cultural and military point of view. The modern state has special organs, through which the central state administration manages the state affairs in all directions [1]." Bearing in mind that management implies control, it is evident that two centuries ago there was the civil control of all state functions including the military one. 
The modern state has many more functions than those mentioned by Živojin Mišić. The civil and democratic control of all state functions could not be executed if it were not legally regulated. Therefore, this paper has mainly researched and studied the planning model with elements of the legislative control of the military budget in all phases, starting from planning and concluding with its execution. Since the budget execution implies the spending of financial resources of the Serbian taxpayers, it is inevitable to expect that the legality and purpose of their spending will be continuously controlled. It is particularly important to mention that the "military budget" within the budget of the Republic of Serbia occupies a significant place from the point of view of the amount of defined and allocated financial resources.

In this paper, the military budget is considered to be the financial resources allocated for use to the Ministry of Defence and the Serbian Armed Forces for each budget year within the Law on Budget of the Republic of Serbia.

\section{PLANNING MODEL IN THE MINISTRY OF DEFENCE AND THE SERBIAN ARMED FORCES}

At the beginning of the 21st century, in the Ministry of Defence and the Serbian Armed Forces a reform in the field of planning was carried out in order to create conditions for efficient management of the Armed Forces of the Republic of Serbia. Since the strategic planning was pushed to the margins in the years before the mentioned reform, there were no mechanisms that would provide sufficient information on whether the defined objectives and tasks of the defence system were successfully implemented, i.e. whether the adequate allocation of the resources for the execution of these objectives was carried out. Practically, long-term planning, as the function in the defence system, did not exist at that time, and it was reduced to one-year budgeting of the defence needs. Inertia was expressed in the allocation of the budget funds according to certain purposes, which was manifested by the appearance of approving the funds increased by the percentage of inflation according to all accounts of economic classification, so that the structure of the defence budget has not changed over the years. A special problem was the inadequate structure of the military budget, dominated by personnel costs, as shown in Figure 1.

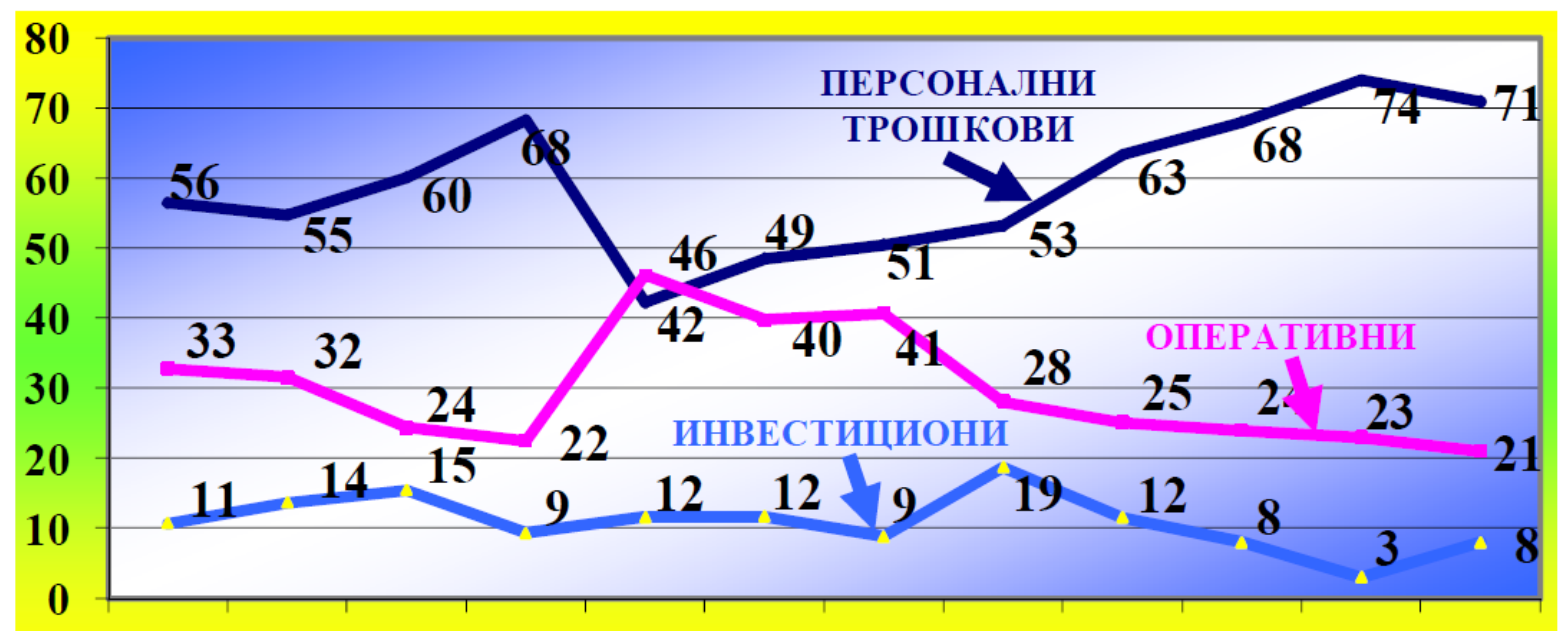

1995. 1996. 1997. 1998. 1999. 2000. 2001. 2002. 2003. 2004. 2005. 2006.

Figure 1.

The structure of expenditures and revenues of the military budget of the Republic of Serbia

The data for the charts in Figure 1 and Figure 2 have been obtained from the Budget and Finance Sector of the Ministry of Defence of the Republic of Serbia. Figure 1 shows the total expenditures and revenues of the Ministry of Defence in the period from 1995 to 2006 by categories of expenditures, expressed as percentage. 


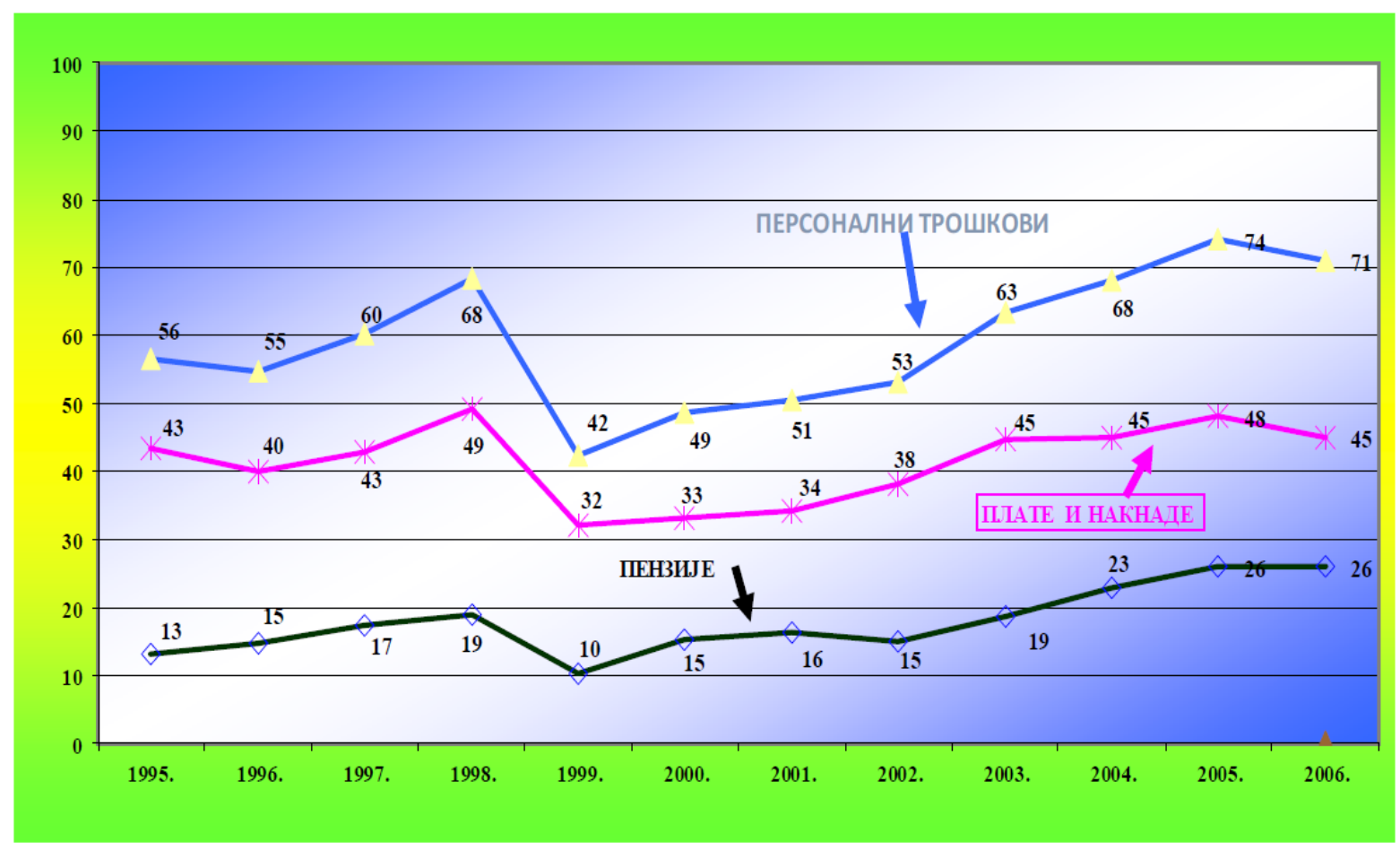

Figure 2.

The structure of personnel expenditures of the military budget of the Republic of Serbia

The greatest percentage share in the total expenditures and revenues of the military budget in the review period are personnel expenditures for salaries, pensions and allowances of the professional members of the Serbian Armed Forces. The lowest percentage share of personnel expenditures in the total expenditures and revenues of the military budget was in 1999, during the NATO aggression on our country. At the time, operational expenditures amounted to $42 \%$ of the total military expenditures, personnel $46 \%$, and investment standard $12 \%$. The greatest share of personnel expenditures in the total military expenditures was recorded in 1998 and $2005,68 \%$, that is $74 \%$, respectively.

Since personnel expenditures consist of the expenditures for salaries, allowances and pensions in the review period, Figure 2 shows the share of salaries and allowances, as well as pensions in total expenditures. The military pensions had the lowest share in 1999, and the highest in 2005 and 2006.

The trend of growth in the share of personnel expenditures in the total military expenditures was recorded immediately after 1999 until 2005, when it peaked at 74\%, while operational expenditures amounted to $23 \%$ of the total military expenditures, and investment only $3 \%$. The paradox was greater that even those $3 \%$ of investment was not spent in 2005, due to the fact that these were completely insufficient funds to maintain the existing capabilities, let alone to develop new ones. Due to the lack of financial resources for the procurement of the military equipment in 2005, the lack of development plans, as well as the lack of defined priorities and procedures, in such circumstances, the management of the defence system could not decide on what to invest available funds, so they remained largely unspent.

Therefore, the decision was made, at the highest level, to develop the defence planning model that would establish the mechanisms for continuous maintenance of the existing and development of new capabilities in accordance with possibilities and available financial resources. Of course, first of all, strategic and long-term planning documents, which would define the percentage of funds allocated from GDP for the defence purposes, should have been adopted by the democratic control in the parliamentary procedure. 
It should be emphasized that the Yugoslav People's Army (YPA) had a very organized system and model of planning, but in the period that followed the dissolution of the Socialist Federal Republic of Yugoslavia (SFRY), there was discontinuity in the field of planning. The last long-term military plan was made during the YPA. The period of immediate war events in the former SFRY, the dissolution of the SFRY, as well as the NATO aggression on the State Union of Serbia and Montenegro, can be characterized as very unfavourable for the planning and development of the Armed Forces. Namely, in that period there was not a single military long-term planning document. There were only the documents defining the defence policy such as the Defence Strategy and the White Paper. The development of the Strategic Defence Review (2007) represents the first step in creating and establishing a normative and planning framework, because in it, in addition to the long-term vision of the development of the Serbian Armed Forces (until 2015), concrete commitments for the defence system reform were made in the following medium term (until 2010).

Figure 3 shows the defence planning model adopted in 2007.

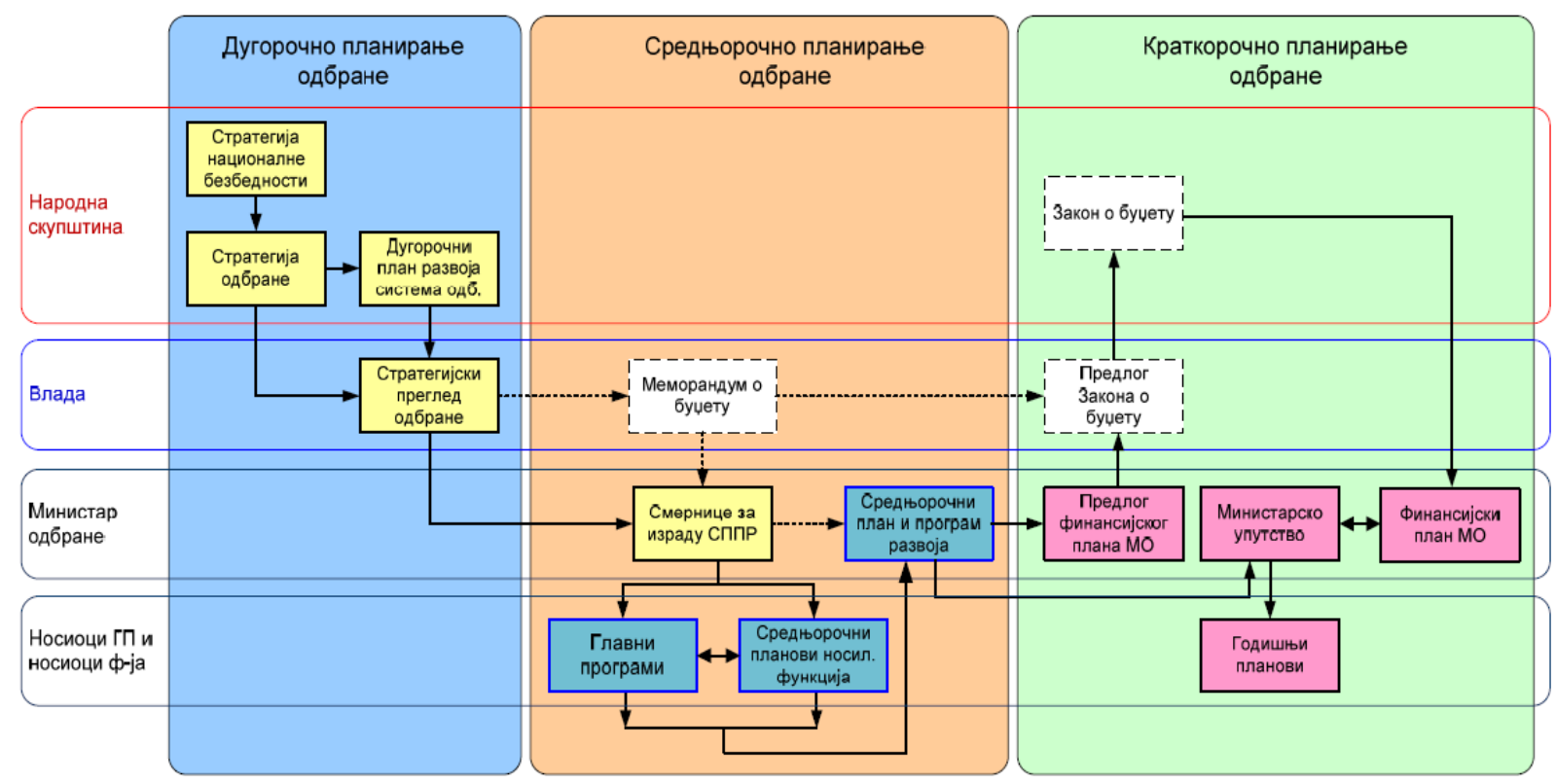

Figure 3.

The defence planning model ${ }^{1}$

This is also the first planning model in the Ministry of Defence and the Serbian Armed Forces. The civil and democratic control was entirely established by the control of the National Assembly over the planning and executive function of the Ministry of Defence. The adoption of the National Security Strategy, the Defence Strategy and the Long-Term Plan for the Development of the Defence System are within the competence of the National Assembly of the Republic of Serbia. The mentioned strategies and plans define the long-term objectives of the defence system development for maintaining the existing and developing new defence system capabilities, and also the percentage of financial resources allocated from gross domestic product (GDP) to finance the maintenance and development of planned capabilities. Figure 3 shows that the Law on Budget is also adopted in the National Assembly of the Republic of Serbia, and it allocates financial resources to the Ministry of Defence. Thus, the continuity in planning and providing financial resources for maintaining and developing the capabilities of the Serbian Armed Forces in the long run has been secured.

However, after the adoption of the first Model of the defence planning and the first Regulation on planning, programming, budgeting and execution in the Ministry of Defence and the Serbian Armed Forces in 2008, problems arose in the implementation phase, therefore it was necessary to start im- 
proving and modifying such Model. Soon after the first budget year, the planning Model was changed and the new Regulation on planning, programming, budgeting and execution in the Ministry of Defence and the Serbian Armed Forces was adopted in 2010 (Figure 4).

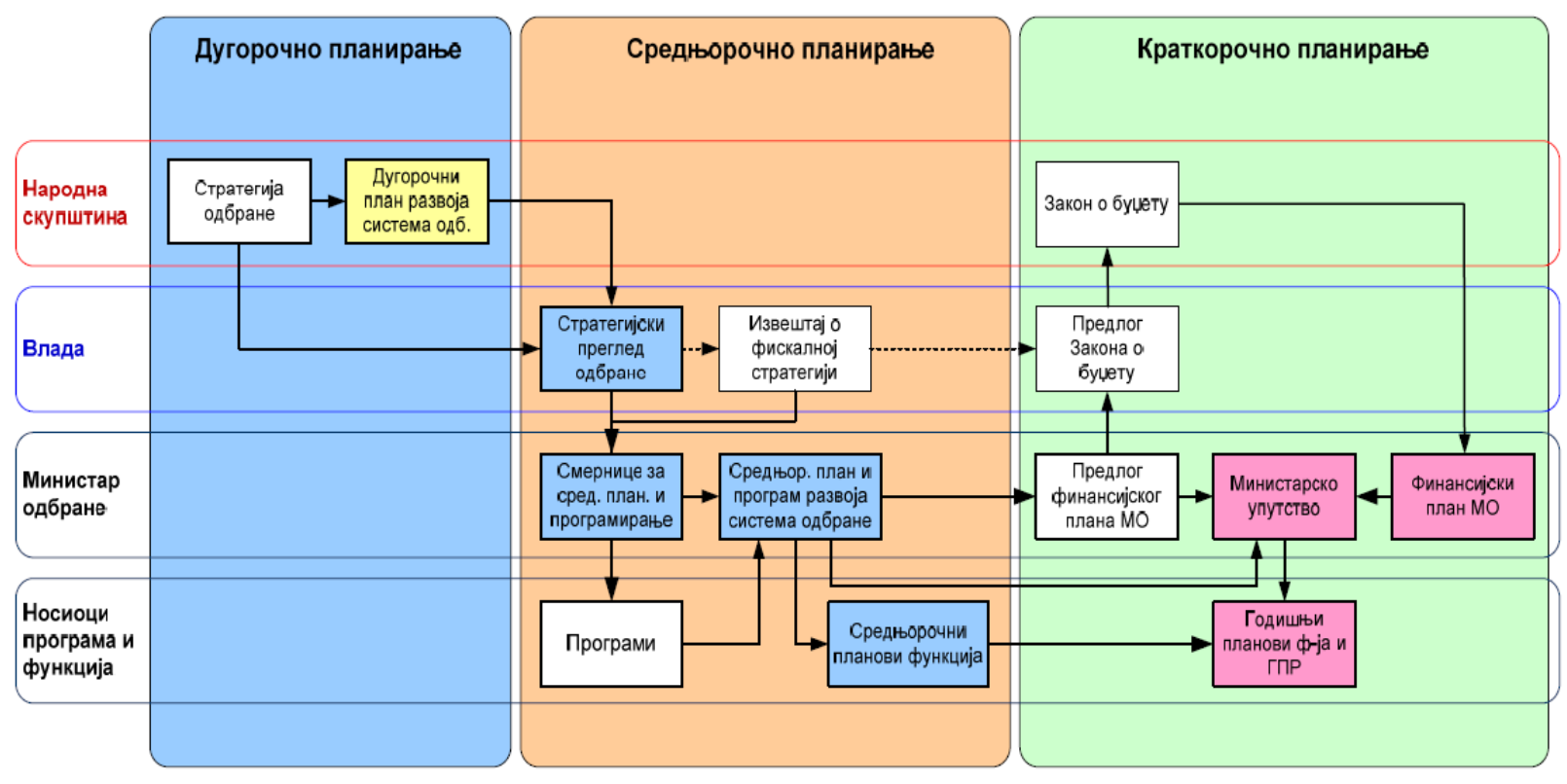

Figure 4.

The defence planning model ${ }^{2}$

In addition to the harmonization with the republic legislation, that is, the abolition of the Memorandum on the budget adopted by the Government of the Republic of Serbia, the Report on Fiscal Strategy, which is also adopted by the Government, was introduced. The National Security Strategy, as an interministerial document, is no longer in the planning Model, and the Strategic Defence Review is no longer a long-term, but a medium-term document. However, the most important thing is that the main programmes have been abolished, and the programmes introduced. The Law on the Budget System of the Republic of Serbia stipulates that the main programmes are interministerial and that financial resources cannot be transferred between the main programmes during the budget year! Since the first version of the Regulation on planning, programming, budgeting and execution in the Ministry of Defence and the Serbian Armed Forces envisaged that there would be 13 main programmes in the defence system, the distribution of funds and their execution was a huge problem, so changes had to be made in an urgent procedure. The adoption of the new Regulation on planning, programming, budgeting and execution in the Ministry of Defence and the Serbian Armed Forces in 2010 created opportunities to approach planning the development of the Armed Forces mainly from an economic point of view, which is characterized by the following: the need for the most efficient use of funds available for certain purposes; the impact of the consequences of the decisions made in the present on the quality of the development in the future; the necessity to be effective, i.e. to achieve the set objectives with the really available funds and the obligation to legally dispose of and permanently control the use of funds to meet the planned needs, although these funds are very limited [2].

Bearing in mind this view, i.e. limited financial resources, the defence planning Model should enable the development objectives to be conducted in the absence of resources, as shown in Figure 5, in order to maintain the existing capabilities, as well as develop new capabilities of the defence system. The strategic gap must not jeopardize the implementation of the defence system development plans. 


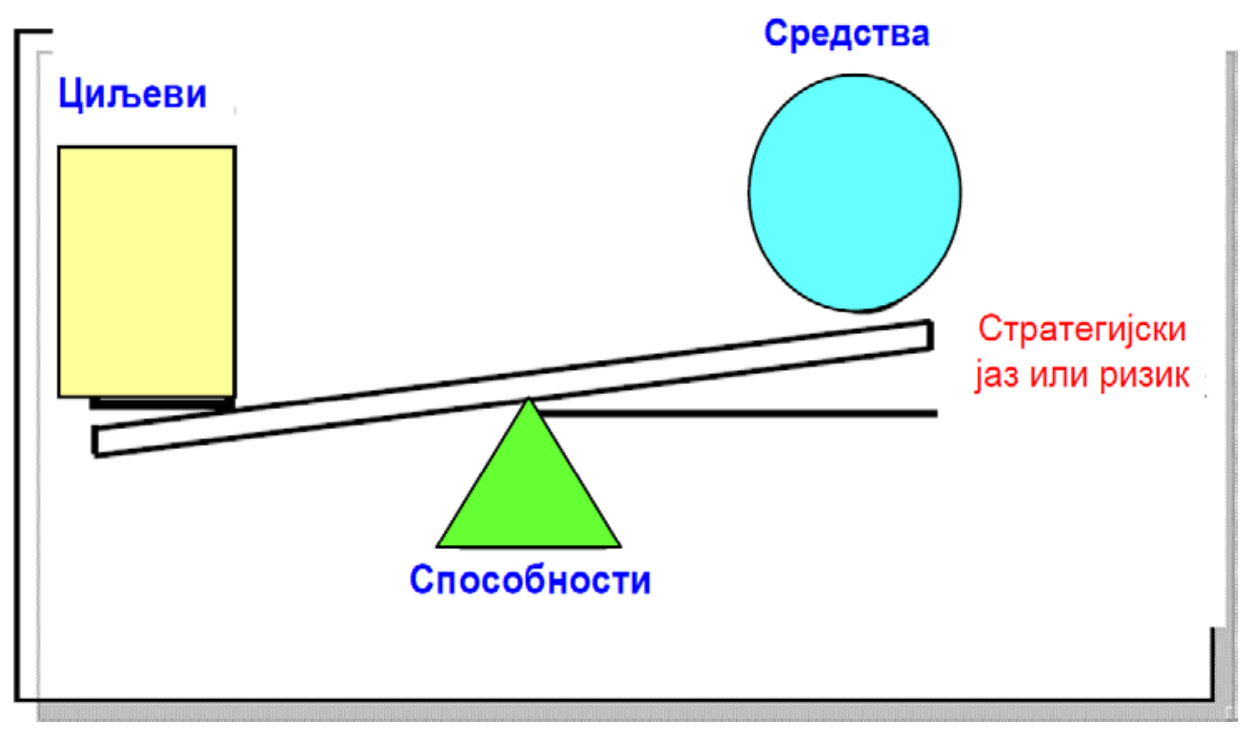

Figure 5.

Defining capabilities in relation to objectives and funds [3]

The civil and democratic control have a huge impact on planning the development of the new defence system capabilities, as shown in both planning models. The control of the military budget during its adoption is thus entirely in the National Assembly of Serbia. However, the control of the execution of the military budget takes place in several phases, and in the continuation of the paper it will be presented in its entirety, as internal in the MoD and SAF and as external by the National Assembly of the Republic of Serbia.

\section{THE CONTROL OF THE MILITARY BUDGET IN THE MINISTRY OF DEFENCE AND THE SERBIAN ARMED FORCES}

The system of internal control is crucial for the efficient operation of every organization. The control activities include written procedures that should ensure the achievement of the organization's business objectives. They are established to provide "reasonable assurance" that potential risks which jeopardize the achievement of business objectives are limited to an acceptable level. The control should take place throughout the organization, at all levels and functions, such as: approvals, delegation of powers, checks, harmonization, review of work results, security of funds, separation of duties, etc [4].

The essential system of internal control is a set of principles, methods and procedures for monitoring the achievement of established objectives, measuring performance, timely availability of accurate information and taking corrective measures in cases of deviations. Thus, the control system is a system of communication from the top to the bottom and from the bottom to the top [5].

The budget control is a series of measures and procedures that follow the procedures of the budget execution in accordance with the purpose and legislation, and also includes the evaluation of $3 \mathrm{E}$ (economy, effectiveness and efficiency).

The internal control of the military budget in the MoD and the SAF is not specifically defined from the aspect of disposal and spending of the budget funds, which does not mean that it does not exist and is not organized. On the contrary, it is present in all units and institutions that dispose of the budget funds because it is included in the regular duties of the ordering party, accountant and other persons who dispose of and manage the budget funds [4]. 
On the basis of the Regulation on Financial Operations in the MoD and the SAF, the internal control system includes all measures that should provide:

1) implementation of laws, regulations, rules and procedures;

2) successful operation of the funds users;

3) economy, efficiency and purposeful use of funds;

4) protection of funds and investment from loss, embezzlement, misuse and corruption;

5) integrity and reliability of the accounting data, records and financial statements.

Considering that the defence system is the direct budget user, that in relation to other direct and indirect users of the budget funds it disposes of a greater part of the budget of the Republic of Serbia, it is inevitable that special attention is paid to the control of the military expenditures. The presentation of the budget of the Republic of Serbia in the period from 2013 to 2021 is given in Figure 6. The budget revenues, expenditures and costs and the military expenditures that are part of the total expenditures and costs of the budget of the Republic of Serbia are shown separately.

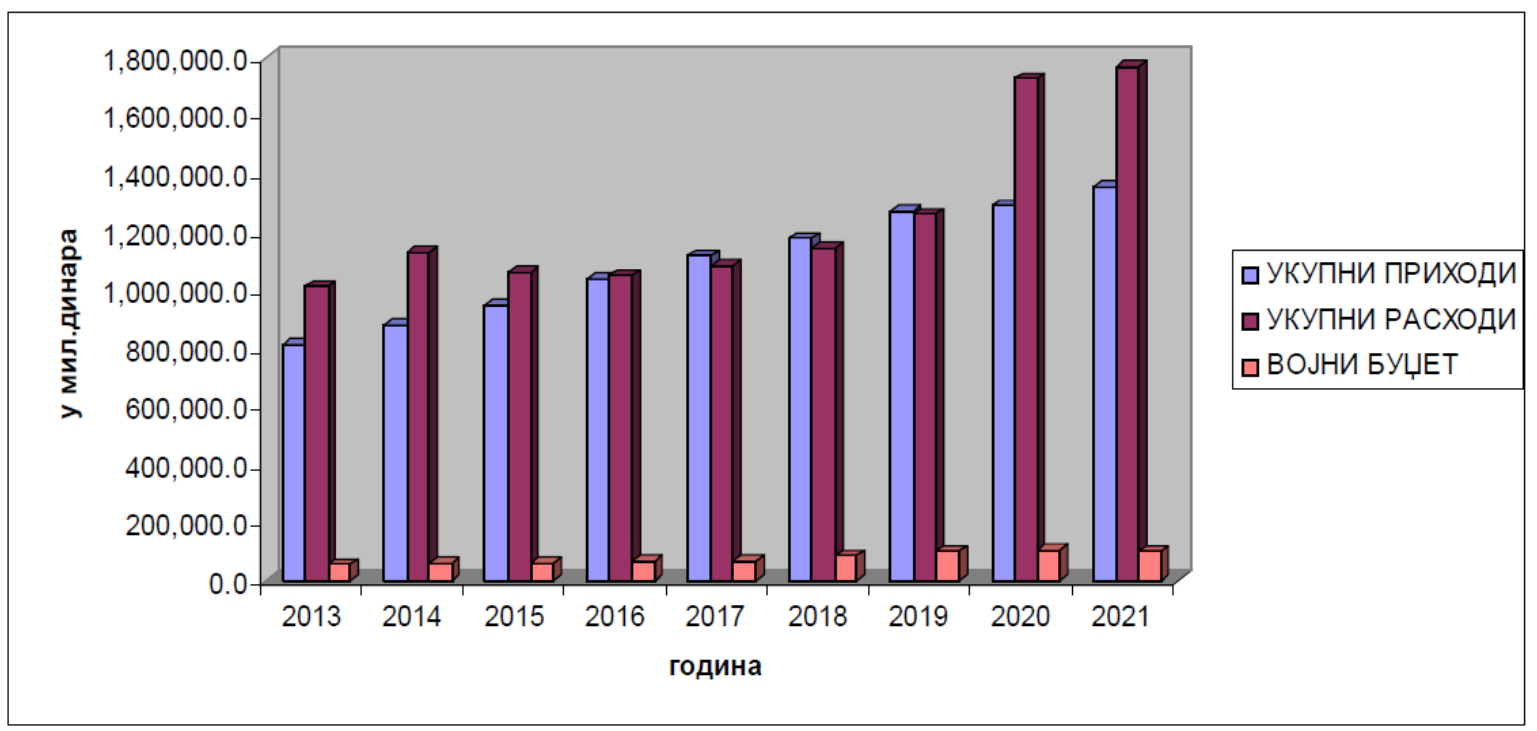

Figure 6.

Revenues and expenditures of the budget of the Republic of Serbia

If we analyze the nominal amount of the funds allocated by the state for the defence in the review period, it can be concluded that the state increases the percentage from year to year, and also the nominal amount of the defence allocation, which can be seen from Figure 7. Although the Covid-19 pandemic has had a significant impact on the creation of GDP, and thus on its distribution, our defence system is still financed in accordance with the missions and objectives of the Serbian Armed Forces. 


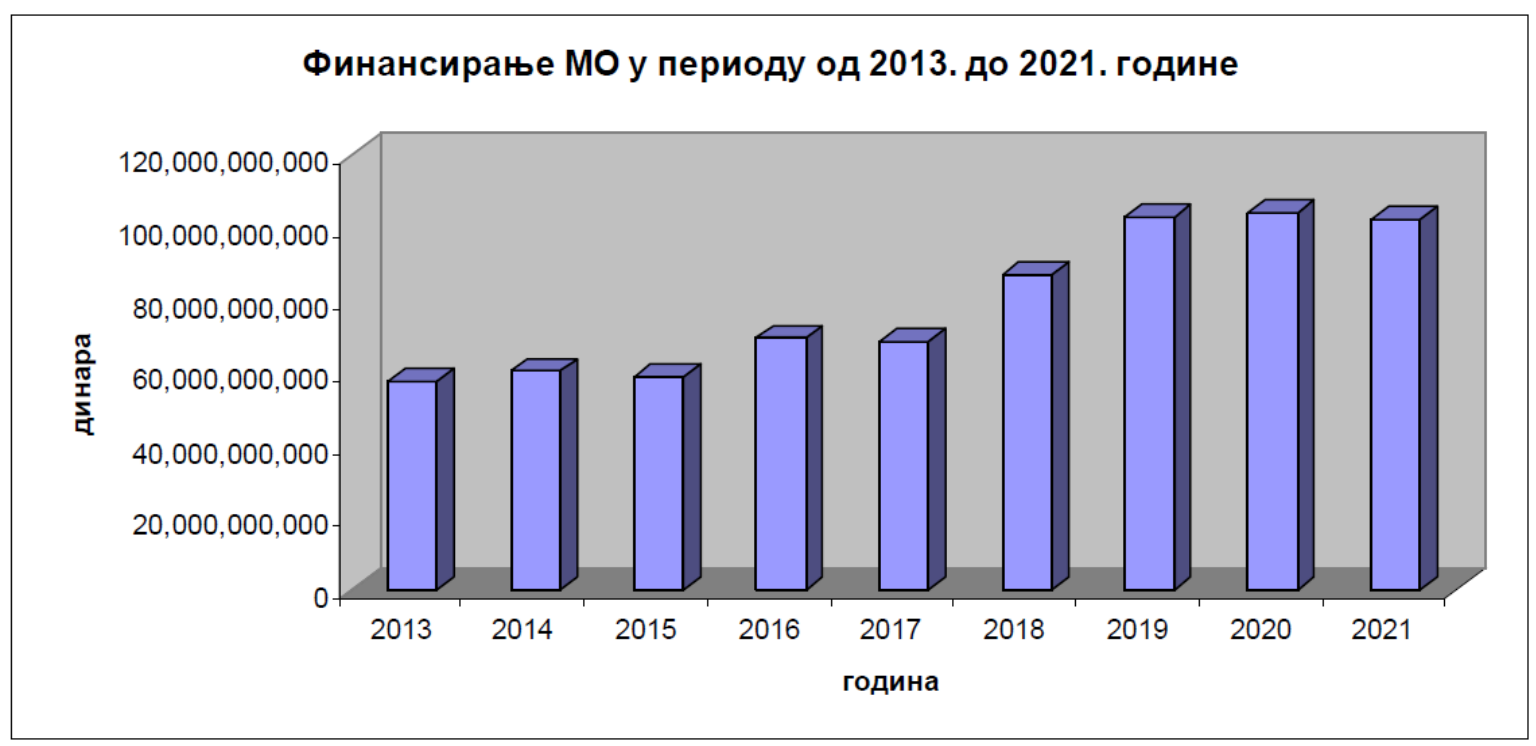

Figure 7.

The defence system financing

Figure 8 shows the percentage share of the military budget in the GDP of the Republic of Serbia.

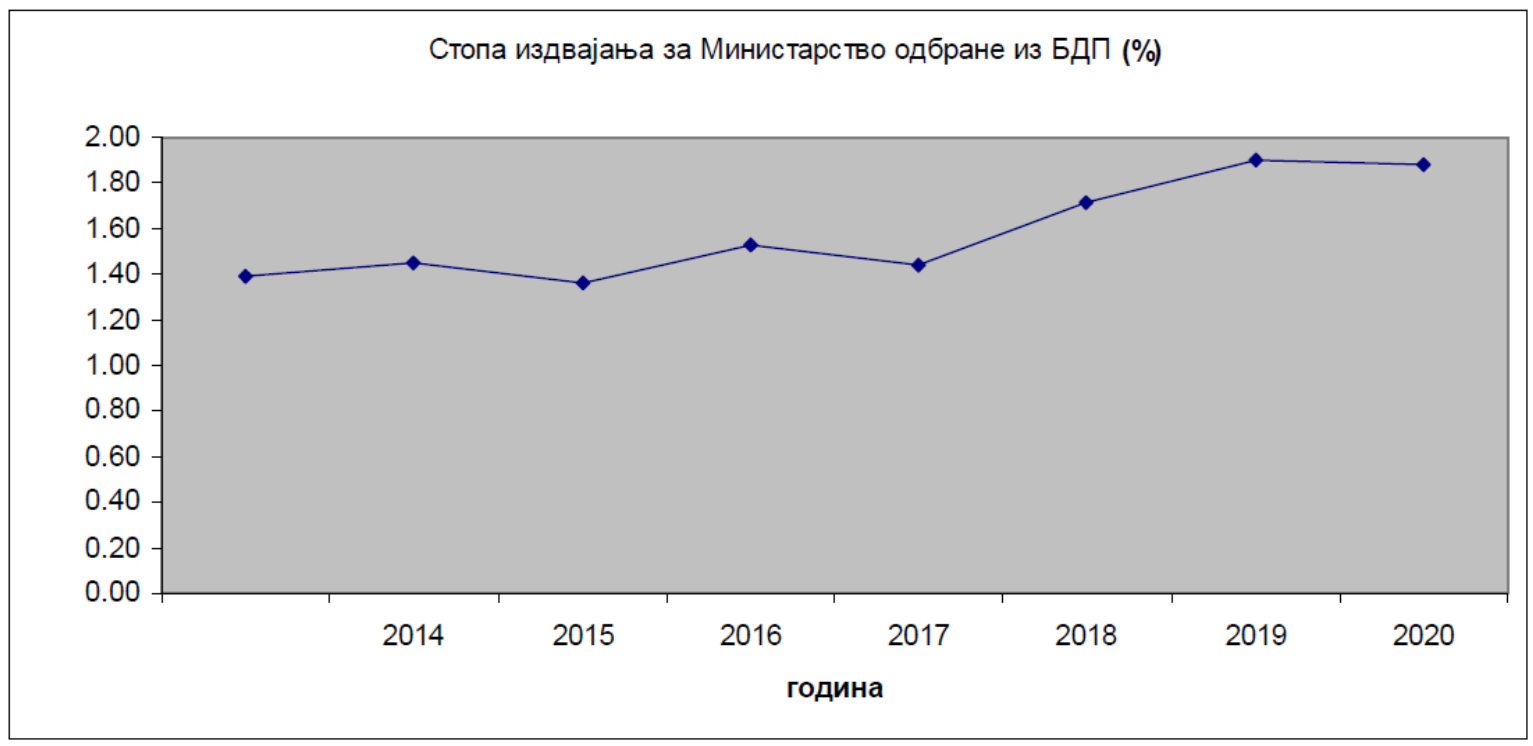

Figure 8.

The percentage of the military budget allocations from GDP

As already mentioned, the percentage of the financial resources that the state allocates in the review period has positive growth. It is very important to mention that for the first time the commitment from the Long-Term Plan for the Development of the Defence System to allocate 1.4\%, that is $1.8 \%$ per year from GDP for the needs of developing the military capabilities, has been respected in the Serbian Armed Forces. In the previous period, the allocations were hardly close to the proclaimed commitment. However, it can be concluded that in the review period, the allocations are even higher than the proclaimed ones, although the Covid-19 pandemic has been present in the economy and lives of all citizens for three years. The reports on GDP growth for 2021 are not known, so there is no data for that year. 
The data used for all charts in this paper are taken from the Laws on Budget of the Republic of Serbia in the review periods.

On the basis of the presented graphs, it is clear that the state is making huge efforts to finance the military budget in accordance with its commitments. Therefore, the task of the management of the defence system is that these funds are spent purposefully, economically, efficiently and effectively, as well as to be controlled at all levels.

The internal control, as a rule, is organized by [4]:

- commanders from the fourth to the central level, over the work of subordinate persons and bodies;

- commanders from the fourth to the central level, over the work of subordinate units and bodies;

- financial bodies within the first, second and third level and subordinate organizational units;

- financial authorities within the fourth level over the management, disposal and use of funds;

- experts in logistics bodies and other bodies that have funds at their disposal.

The organization of the internal control is in the competence of the commanders, and also the Sector in charge of the finance and budget in the MoD and the SAF. The mechanisms of financial management and control in the MoD and the SAF defined by the Regulation on Financial Operations in the MoD and the SAF, have been established. In addition to the established mechanisms for the control of the purposeful and legal spending of the financial resources of the military budget, there is also the Internal Audit in the MoD and the SAF.

Regarding the defence system, the Internal Audit in the MoD was established as a narrower internal unit, as the Internal Audit Section. It is a functionally independent organizational unit in the MoD, which directly reports to the head of the public funds users [6].

The tasks of the Internal Audit Section in the MoD are defined by the Regulation on Internal Organization and Systematization of Work Positions. These are: reviews of compliance with the existing financial regulations, instructions and procedures; evaluation of the effectiveness of internal control; evaluation of effective use of funds; review of the reliability and integrity of the way records and reporting are kept; payments and contracts; reviews of accounting reports; examination of irregularities; regularity of revenue collection and their records; security of the property and its inventory; review of the budget reallocation, in order to ensure legal compliance and provide sufficient funds and other tasks within the responsibility of the Section. While performing the defined tasks, internal auditors in their work, in addition to regulations at international and national level, are guided by internal acts: the Internal Audit Charter, the Code of Ethics, as well as strategic and annual plans, generating operational plans and audit tasks plans. The Internal Audit Charter is an internal act signed by the head of the internal audit service and the head of the organization, which defines the role, powers and responsibilities of the internal audit in the MoD. It is the official document that determines the position of audit in the organization and addresses several issues: 1) the role of the internal audit, 2) the scope of the internal audit, 3) the independence of the internal audit, 4) the duties of the internal audit head, 5) the duties of the head of the organization, 6) reporting and communication, 7) cooperation with other institutions.

The subject of the internal auditor's examination is the entire business focused on the execution of assigned missions and tasks, through recommendations to the military management. These are most often recommendations and advice regarding possible corrective actions, which would eliminate the observed deviations from the standards and planned objectives [6]. 
It is evident that it is not possible to conduct the audit of all organizational units of the MoD and the SAF, so it is necessary to focus on high-risk fields and in some organizational units, commands and institutions. The internal audit should be adapted to the circumstances within the auditee and based on risk assessment, in order to achieve a higher level of effectiveness where necessary [6]. Moreover, the auditor's experiential method is used, which is based on the table for calculating risk index.

\section{THE STATE AUDIT INSTITUTION}

The State Audit Institution, the highest body for auditing public funds in the Republic of Serbia, was established by the Law on the State Audit Institution in 2005. Soon after its establishment, in November 2008, the State Audit Institution became a full member of the International Organization of Supreme Audit Institutions (INTOSAI), and a part of the European Organization of Supreme Audit Institutions (EUROSAI) on June 23, 2009. In order to better understand the importance of the establishment, and then the membership in internationally recognized audit institutions, we should briefly look at the social and political events in our country during the 1990s, as well as in the first years of the 21st century.

The highest supervisory body in the Republic of Serbia is the National Assembly of the Republic of Serbia. In order to adequately exercise the supervisory function, the deputies of the National Assembly are assisted by the State Audit Institution (SAI) [7]. The Constitution of the Republic of Serbia defines the SAI as the highest body for the audit of public funds in the RS, it is independent, subject to the supervision of the National Assembly of the RS, to which it is responsible [8]. The legal position of the SAl is defined in the form of an institution that is autonomous, independent and has the status of a legal entity [9]. The State Audit Institution performs its supervision according to a single document the Terms of Reference of the SAl (hereinafter the ToR). As defined in Article 1 of the ToR, it regulates in more detail "the manner and procedure by which the State Audit Institution (hereinafter the Institution) performs its audit competence, advising users of public funds, reporting to the National Assembly, organization and composition of the Institution, publicity of the work, decision-making manner and other issues of importance for the work of the Institution." For efficient and effective implementation of audit, it is necessary for the SAI to perform certain activities [7], which are shown in Figure 9.

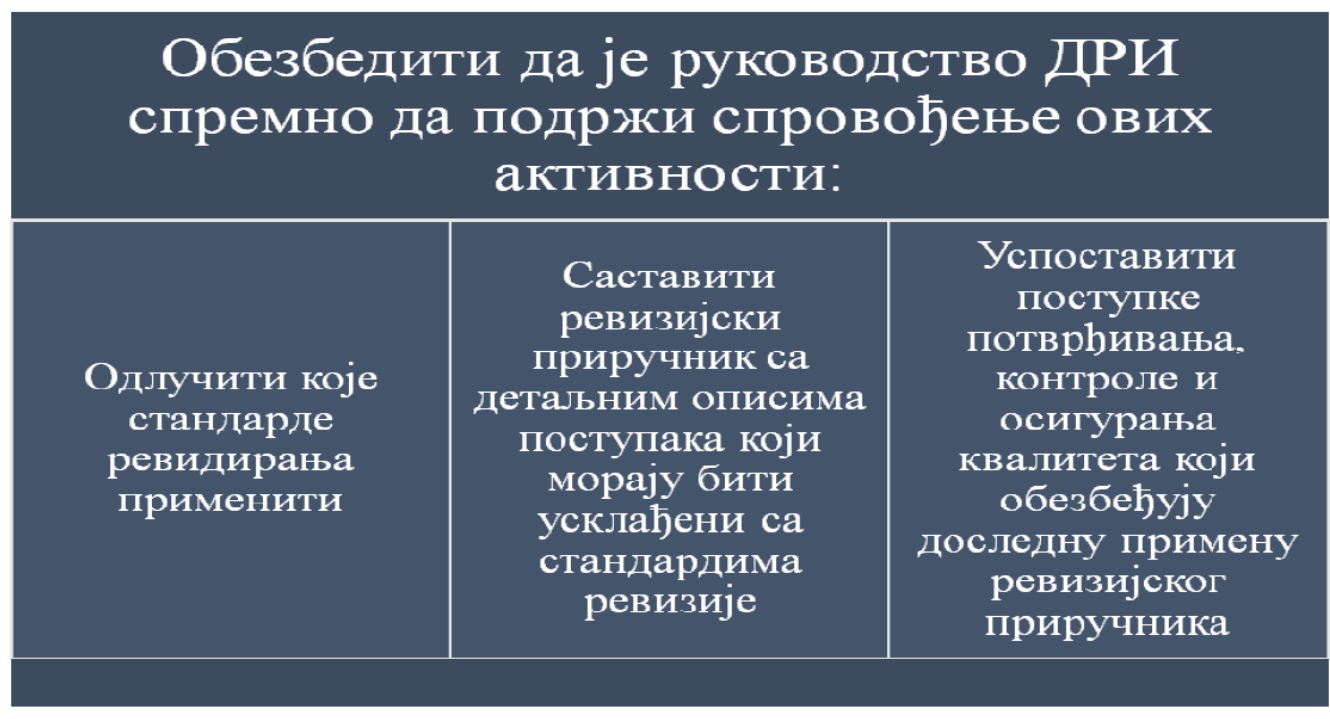

Figure 9.

The activities that the SAI should perform for efficient and effective audit

The State Audit Institution, like other important organizations, has defined its vision and business mission. From the management aspect, the vision can be most simply explained as a long-term de- 
sired result, the clear vision of the future situation. More simply, the vision of the organization shows the ideal future state of that organization ${ }^{5}$, which is achieved by the execution of the set objectives, i.e. doing business within its competencies. The vision also defines the level of social responsibility of the organization, as well as the integrity of the organization and promotes them as key or core values $^{6}$. The mission, on the other hand, should show how the organization will fulfill its vision, that is, how it will really reach the ideal future state. In the shortest way, the mission tells us the purpose of the organization, the standards of behaviour, and the value system that is implemented. The vision and mission of the State Audit Institution are publicly available, are highlighted on the SAI website ${ }^{8}$, and are presented in Figure 10:

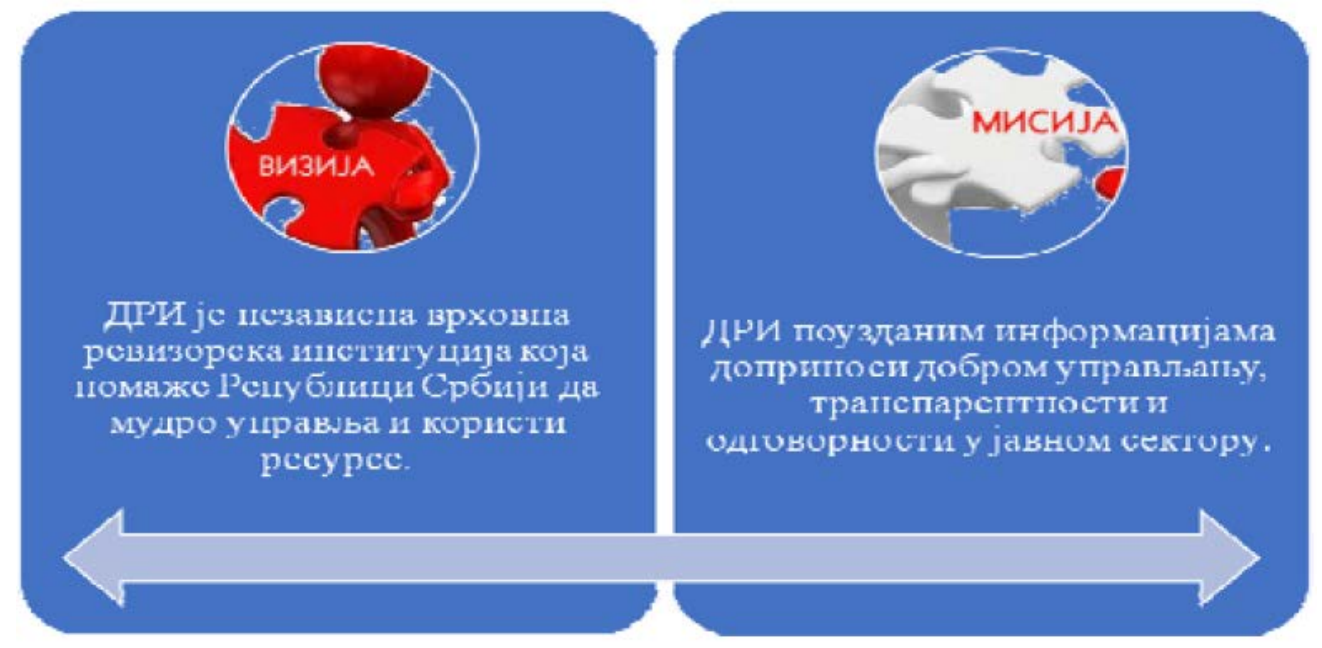

Figure 10.

The SAI vision and mission

The audit performed by the State Audit Institution is conducted in accordance with the adopted Annual Audit Programme for a specific year, which also decides on the operations of an entity that will be the subject of the audit. The State Audit Institution in Serbia may perform the audit of operations, as shown in Figure 11, of the following users of public funds:

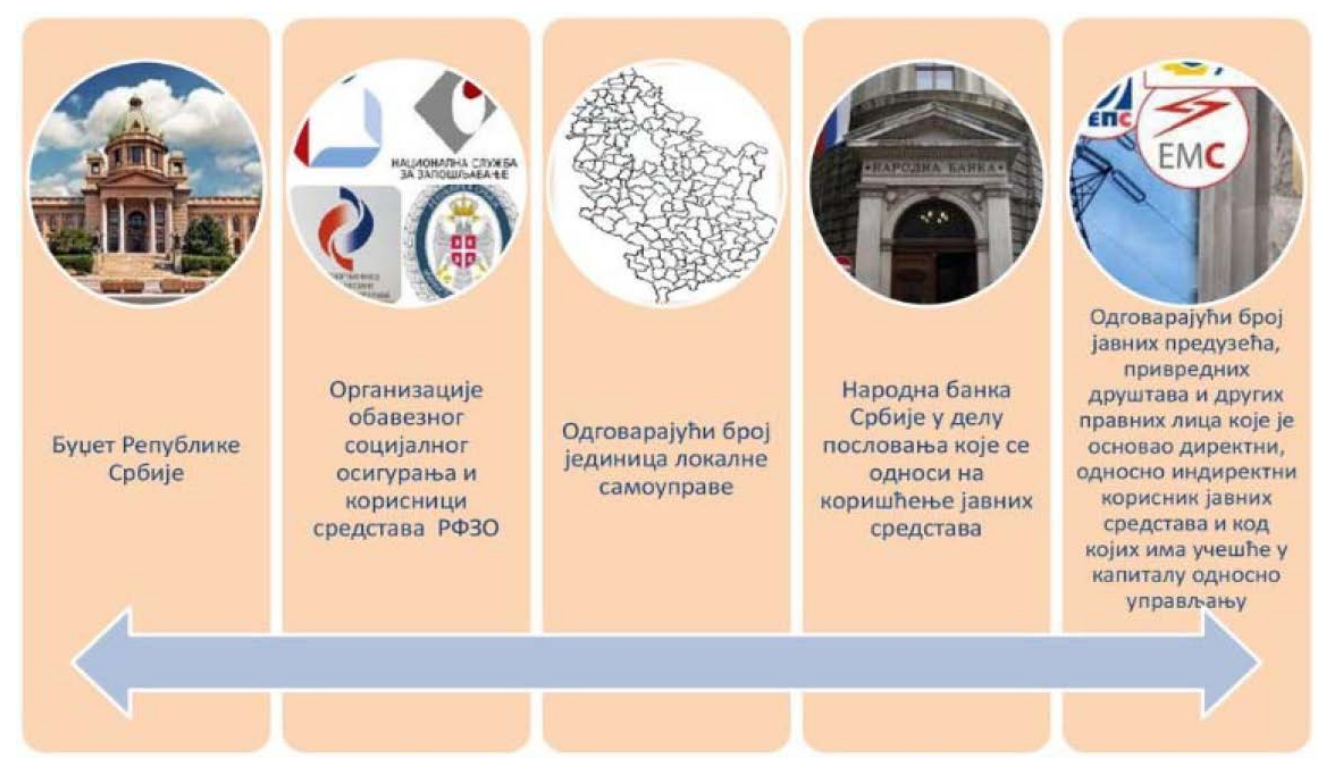

Figure 11.

The mandatory entities of audit during a year 
- direct and indirect budget users and organizations of mandatory social insurance;

- budget funds established by a special law or by-law;

- the National Bank of Serbia, in the part related to the use of public funds and business with the state budget;

- public enterprises, companies and other legal entities established by a direct or indirect user of public funds;

- legal entities in which direct or indirect users have a share in the capital, i.e. in management, and legal entities established by legal entities in which the state has a share in the capital, i.e. in management;

- legal and natural persons who receive grants and other non-refundable subsidies or guarantees from the Republic, territorial autonomies and local authorities;

- entities engaged in the acceptance, safe keeping, issuance and use of public reserves;

- political parties, in accordance with the law defining the financing of political parties;

- beneficiaries of the EU funds, donations and assistance from international organizations, foreign governments and non-governmental organizations;

- contracting parties in connection with the execution of international treaties, agreements, conventions and other international acts, when it is defined by an international act or when it is determined by an authorized body;

- other entities that use funds and property under the control and disposal of the Republic, territorial autonomies, local authorities or mandatory social security organizations [7].

The role of the SAI is such that it helps the National Assembly to respond to various risks that the Republic of Serbia is facing, and which are more and more present in the modern environment. The public sector is particularly sensitive to the mentioned risks, and the SAI has to ensure the execution of the so-called " $3 \mathrm{E}$ " principles - efficiency, economy and effectiveness in spending extremely limited public funds. Since the SAI is a relatively new institution, it is realistic to expect that its full significance will be seen in the years to come.

\section{CONCLUSION}

The paper presents all forms and models of the military budget control - from the process of preparation until its execution, i.e. spending of financial resources. The civil and democratic control of the military budget is defined by the Constitution, as the highest legal act in the Republic of Serbia.

The planning model developed for the needs of our defence system is modern and in accordance with the existing normative and legal acts of the Republic of Serbia. The control mechanisms enable continuous and uninterrupted financing of the maintenance of the existing and development of new capabilities of the defence system, even in situations of limited financial resources.

The internal control of the military budget is stipulated by regulations in the Ministry of Defence and the Serbian Armed Forces, whose role is to spend the funds allocated to the defence system purposefully and in accordance with regulations. Each intention of unintended or illegal spending of financial 
resources is eliminated and not allowed by timely prior control in the Serbian Armed Forces units and institutions. If, on the other hand, there is an omission in the units and institutions, intentional or not, such an intention is suspended by timely control in the Accounting Centre of the MoD and the SAF and the payment of funds is not allowed. However, if such a payment is made in the Accounting Centre, subsequent control by the Criminal Investigation Group of the Military Police or the Defence Inspectorate reveals the perpetrators of abuse of office, who are further subject to investigation and further measures in accordance with the legislation of the Republic of Serbia.

The internal audit of the MoD, in accordance with the existing regulations, most often performs, among other things, the control of the procedures and regulations in the MoD and the SAF. Internal auditors make recommendations, which the supervised entity of internal audit may or may not implement. If the supervised entity refuses to implement the recommendations of internal auditors, they may propose to the Minister of Defence to order the supervised entity their implementation. The Minister of Defence decides whether to issue such an order.

The role and importance of the state audit, primarily today, in the era of modernization and globalization, has become particularly significant. In the coming period, in the months and years ahead, there will inevitably be an increase in the quality of the state audit because the potential offered by modern technology will be used more and more. By establishing unique platforms, such as e-Government, the time comes when unified databases will be formed at the state level and it will not be necessary to take double actions for the same objective. Connecting all segments of the public sector into a single system will lead to additional benefits.

The greatest challenge today, and in the near future, will be the fight against the Coronavirus and alleviating the consequences that the pandemic has already caused, and there will be many more. The great influence of the state, the provision of various types of financial assistance, the accelerated adoption of regulations for dealing with extraordinary circumstances will be a real challenge for audit in the coming period. There are many questions that can be asked, as well as risks that can lead to illegal disposal of funds and numerous embezzlements in the society, and the world in general. However, in our defence system such possibilities are minimized by the existing organization of internal control. The civil and democratic control should participate in the planning process, and also control the military budget because the defence system is a direct user of the budget funds.

It can be concluded that the goal of the control of the military budget is by no means, and should not be, exclusively the control of legality and purpose of spending funds, but it should be preventive control that allows establishing or developing mechanisms to prevent the misuse of funds. Moreover, in the situations of limited financial resources, the control mechanisms should enable optimal use of available funds for the development of the defence system capabilities.

\section{Acknowledgment}

The paper was written as a part of the research on the scientific project of the Military Academy of the Defence University „The military in the political system of Serbia”, which is financed by the Ministry of Defence of the Republic of Serbia (project number VA-DH/1/19-21)

\section{Endnotes}

'Made in accordance with the Regulation on planning, programming, budgeting and execution in the MoD and SAF, 2008.

"Made in accordance with the Regulation on planning, programming, budgeting and execution in the MoD and SAF, 2010.

${ }^{3}$ www.dri.rs , accessed on April 29, 2021.

${ }^{4}$ The Terms of Reference is an internal document of the SAI published in the "Official Gazette of the RS", No. 9/2009. 
${ }^{5}$ http://imi.fon.bg.ac.rs/inzenjering-procesa/wp-content/uploads/sites/12/03a-Identifikacijapredmeta-rada_2017.pdf, accessed on May 17, 2021.

${ }^{6}$ https://dynamicsignal.com/2020/08/07/company-values/, accessed on May 17, 2021

7http://imi.fon.bg.ac.rs/inzenjering-procesa/wp-content/uploads/sites/12/03a-Identifikacijapredmeta-rada 2017.pdf, accessed on May 17, 2021

${ }^{8}$ https://www.dri.rs/o-nama/uloga-dri--vizija--misija.72.html, accessed on May 17, 2021

\section{REFERENCES}

1. Žugić R, Milunović M, Stanković S. Osnovi revizije i kontrole. Medija centar Odbrana. 2020. [Google Scholar]

2. Program razvoja i uvođenja sistema PPBI u MO i VS. 2006.

3. Stanojević S, et al. Teorija državne revizije. Kragujevac: Centar za ekonomska i finansijska istraživanja. 2018. [Google Scholar]

4. Radojković MN, Žugić R, Trandafilović SK. Značaj interne revizije za Ministarstvo odbrane i Vojsku Srbije. Vojno delo. 2016;68(2):212-220. [Crossref] [SCIndeks] [PDF] [Google Scholar]

5. Dabić L. Prilog za uspostavljanje nove naučne discipline - pravo revizije javnog sektora. Anali Pravnog fakulteta u Beogradu. 2018;66(3):88-107. [Crossref] [SCIndeks] [PDF] [Google Scholar]

6. Knežević M, Novaković Z, Tešanović B. Praćenje izvršenja rashoda po utvrđenim aktivnostima i programima. In: SYMOPIS 2012. [Google Scholar]

7. Trenerry A. Principles of Internal Control: Incorporating the Learning Outcomes and Content of National Accounting Course Module-Nap 717: Internal Control Principles. UNSW Press. 1999. [Google Scholar]

8. The Constitution of the Republic of Serbia. Official Gazette of RS. 2006;98.

9. Zakon o budžetskom sistemu. Sl. glasnik RS. 2009-2019;br. 54/2009, 73/2010, 101/2010, 101/2011, 93/2012, 62/2013, 63/2013 - ispr., 108/2013, 142/2014, 68/2015 - dr. zakon, 103/2015, 99/2016, 113/2017, 95/2018, 31/2019 i $72 / 2019$.

10. Zakon o reviziji. Sl. glasnik RS. 2013/2018;br. 62 i 30.

11. Zakon o državnoj revizorskoj instituciji. Službeni glasnik RS. 2005-2018;br. 101/2005, 54/2007, 36/2010 i 44/2018 - dr. zakon.

12. Etički kodeks za državne revizore i druge zaposlene u Državnoj revizorskoj instituciji. Sl. glasnik RS. 2009;br. 44.

13. Poslovnik Državne revizorske institucije. Sl. glasnik RS. 2009;br. 9.

14. Ministarstvo odbrane Republike Srbije. Pravilnik o finansijskom poslovanju u MO i VS. SVL. 2011-2020;17/11, 3/13 12/14, 9/17 i 4/20. [Google Scholar]

15. Ministarstvo odbrane Republike Srbije. Studija razvoja i uvođenja sistema PPBI. Beograd. 2007. [Google Scholar]

16. Ministarstvo odbrane Republike Srbije. Pravilnik o planiranju, programiranju, budžetiranju i izvršenju u Ministarstvu odbrane i Vojsci Srbije. Službeni vojni list (SVL). 2008;br. 31. [Google Scholar]

17. Ministarstvo odbrane Republike Srbije. Studija optimizacija organizacije i funkcionisanja planiranja, programiranja, budžetiranja i izvršenja u Ministarstvu odbrane i Vojsci Srbije. Beograd. 2010. [Google Scholar]

18. Ministarstvo odbrane Republike Srbije. Pravilnik o planiranju, programiranju, budžetiranju i izvršenju u Ministarstva odbrane i Vojsci Srbije. Beograd. 2010. [Google Scholar]

19. Pravilnik o zajedničkim kriterijumima za organizovanje i standardima i metodološkim uputstvima za postupanje i izveštavanje interne revizije u javnom sektoru. Službeni glasnik RS. 2011/2013;br. 99 i 106.

20. Mišić Ž. Strategija. Beograd: Vojnoizdavački i novinski centar. 1993. [Google Scholar] 


\title{
Kontrola budžeta u funkciji civilne demokratske kontrole vojske u Republici Srbiji
}

\begin{abstract}
Sažetak:
Jedan od bitnih pokazatelja demokratizacije svakog društva jeste ustavno i zakonsko definisanje uloge vojske i mogućnosti njene kontrole. Civilna demokratska kontrola Vojske Srbije prevashodno obuhvata kontrolu upotrebe i razvoja Vojske Srbije, internu i eksternu kontrolu troškova za vojne potrebe, praćenja stanja i obaveštavanja javnosti o stanju priprema Vojske, obezbeđenje slobodnog pristupa informacijama od javnog značaja i utvrđivanje odgovornosti za vršenje vojnih dužnosti u skladu sa zakonom. Instrument finansiranja troškova za vojne potrebe u Republici Srbiji predstavlja državni budžet. Prilikom izrade Nacrta zakona o budžetu planiraju se troškovi za vojne potrebe za budžetsku i naredne dve godine. S obzirom na to da Zakon o budžetu donosi najviše zakonodavno telo - Narodna skupština, osnovni princip demokratske kontrole planiranja troškova za vojne potrebe je obezbeđen. Međutim, realizacija budžeta podrazumeva kontrolu upotrebe budžetskih sredstava, pri čemu je Zakonom o budžetskom sistemu predviđeno više nivoa kontrole, organizovanih kao interna i eksterna kontrola. Internu kontrolu troškova za vojne potrebe, iskazanih u budžetu Republike Srbije, sprovode organi finansijske službe jedinica i ustanova Vojske Srbije, Računovodstveni centar Sektora za budžet i finansije Ministarstva odbrane, Inspektorat odbrane, Vojnobezbednosna agencija i Kriminalističko-istražna grupa i interna revizija Ministarstva odbrane. Eksternu kontrolu budžeta namenjenog za vojne potrebe vrši Državna revizorska institucija i budžetska inspekcija. Cilj kontrole jeste da se utvrdi da li je delovanje Vojske Srbije u skladu sa pozicijom utvrđenom Ustavom, kao i sa politikom koju navedeni predstavnički i izvršni organi vlasti utvrđuju u svojim aktima.
\end{abstract}

Ključne reči: civilna demokratska kontrola; budžet; efikasnost; realizacija 